\title{
Soil - Water Loss and Measures Measure composition of Overhead Power Transmission Lines in Hilly area
}

\author{
YANG Chunxia ${ }^{1}$ *, CHEN Xiaofeng ${ }^{2}, \mathrm{LI} \mathrm{Li}^{1}, \mathrm{Chen} \mathrm{Xi}^{3}, \mathrm{HU} \mathrm{Jia}^{2}$, HONG Qian ${ }^{2}$ \\ ${ }^{1}$ Yellow River Institute of Hydraulic Research YRCC, Key Laboratory of Yellow River Sediment Research of Ministry of Water \\ Resources, Zhengzhou 450003, China \\ ${ }^{2}$ State Grid Economic and Technological Research Institute Co., Ltd. Beijing 102209, China \\ ${ }^{3}$ Economic and Technological Research Institute of State Grid Hubei Electric Power Co., Ltd. Wuhan 430000, China
}

\begin{abstract}
The disturbance characteristics of power transmission line projects are long distance, scattered disturbances, large differences in natural conditions, and diverse types and strengths of soil erosion. These two points are the key to soil and water conservation, Including that identifying the main controlling factors of soil erosion in each construction disturbance area, and adapting measures to local conditions, and setting up water and soil conservation measures for disasters are power transmission lines in hilly areas. This paper took a specific project as an example, analyzed and evaluated the characteristics of water and soil erosion in the project and optimizes the configuration of measures, in order to provide a reference for the arrangement of water and soil conservation measures in the construction of similar projects.
\end{abstract}

\section{Submitting the manuscript}

Under the premise that our country attaches great importance to ecological protection and high-quality development, various industries have to pay attention to the effect of soil and water conservation and ecological restoration in the process of construction while doing well in engineering construction. As an important part of infrastructure construction, transmission line plays an important role in ensuring power safety. At the same time, the ecological environment will inevitably be disturbed and damaged. In addition, the construction of transmission lines involves long lines, great differences in natural conditions, and various types of soil and water loss. Among them, the soil and water loss of transmission line projects in hilly areas is the focus of attention of the transmission line water and soil conservation. Therefore, sorting out the soil and water loss problem in the process of overhead transmission line construction has become the key restricting factor of transmission line construction and environmental counterparts.

In recent two years, Implementation of "releasing management service" and "strengthening supervision" in water conservancy industry have also put forward higher requirements for self-management of soil and water conservation in the process of project construction. Although soil and water conservation work of production and construction projects in various industries has been gradually paid attention to, exploration and practice work has been gradually carried out, but there is no systematic and mature prevention and control measures system to learn from and seriously restrict The project construction and ecological protection win-win strategy implementation. Although the exploration and practice of soil and water conservation in production and construction projects are gradually carried out in various industries, However, it is still in the initial stage, and there is no systematic and mature prevention and control measures system to be adopted, which seriously restricts the implementation of the win-win strategy of engineering construction and ecological protection. Therefore, this paper takes "Zhundong - East China (South Anhui) $\pm 1100 \mathrm{kV}$ UHVDC transmission project" as an example to carry out the research, It is very important to identify the characteristics of water and soil loss of transmission line projects and sort out the allocation system of soil and water conservation measures in various types of areas. This study is very important for the practice of transmission line engineering and has important reference significance for similar projects.

\section{Basic information of the project}

The $\pm 1100 \mathrm{kV}$ UHVDC transmission project from Zhundong to East China (Southern Anhui) is a newly built super large transmission project, including three parts: sending end project, receiving terminal project and line engineering. The $1100 \mathrm{kV}$ DC transmission line starts from Zhundong converter station and ends at Wannan converter station, with a length of $3292.981 \mathrm{~km}$. It involves 71 counties (districts) of 23 cities (prefectures) in 6 provinces of Xinjiang, Gansu, Ningxia, Shaanxi, Henan and Anhui, and 3 watersheds of the Yellow River, the Yangtze River and the Huaihe River. The topography and geomorphology involved $30.4 \%$ of Gobi desert area,

*YANG Chunxia: 445180735@qq.com 
$42.2 \%$ of hilly area and $27.4 \%$ of plain area, Among them, hilly area is the key type area of soil and water conservation.

\section{Analysis of main control factors on soil and water loss}

Similar to other production and construction projects ${ }^{[1-2]}$, the water and soil loss of the project is mainly reflected in the excavation of foundation pit, vegetation damage, surface exposure, loose soil piling, resulting in soil erosion resistance reduced, natural stable catchment system disturbed and other erosion environment changes. The disturbance area and prediction of soil and water loss in different administrative areas of the project are shown in Table 1.

Table 1. Disturbance scope of soil erosion

\begin{tabular}{cccccccc}
\hline \multirow{2}{*}{$\begin{array}{c}\text { Administrati } \\
\text { ve Region }\end{array}$} & $\begin{array}{c}\text { Hilly Area } \\
\left(\mathrm{hm}^{2}\right)\end{array}$ & \multicolumn{2}{c}{ Prediction of soil erosion $(\mathrm{t})$} & \multicolumn{3}{c}{$\begin{array}{c}\text { New increased soil erosion } \\
\left(\mathrm{t} / \mathrm{hm}^{2}\right)\end{array}$} \\
\cline { 3 - 8 } & & $\begin{array}{c}\text { Backgroun } \\
\mathrm{d}\end{array}$ & $\begin{array}{c}\text { Estimat } \\
\mathrm{e}\end{array}$ & $\begin{array}{c}\text { Increas } \\
\text { ed }\end{array}$ & $\begin{array}{c}\text { Backgro } \\
\text { und }\end{array}$ & $\begin{array}{c}\text { Estimat } \\
\mathrm{e}\end{array}$ & $\begin{array}{c}\text { Increase } \\
\mathrm{d}\end{array}$ \\
\hline Xinjiang & 71.65 & 8984 & 14097 & 5113 & 125.39 & 552.82 & 0.57 \\
Gansu & 175.09 & 21985 & 35918 & 13933 & 125.56 & 478.40 & 0.63 \\
Ningxia & 53.67 & 3227 & 8372 & 5145 & 60.13 & 259.03 & 1.59 \\
Shaanxi & 79.95 & 2035 & 5568 & 3533 & 25.45 & 164.05 & 1.74 \\
Henan & 51.6 & 1613 & 4659 & 3046 & 31.26 & 329.03 & 1.89 \\
Anhui & 93.71 & 917 & 2753 & 1836 & 9.79 & 194.97 & 2.00 \\
Total & 525.67 & 38761 & 71367 & 32606 & 73.74 & 365.76 & 0.84 \\
\hline
\end{tabular}

According to the engineering change scheme, the forecast period of construction period in each province is consistent, including 0.75 years ( 9 months) for tower foundation construction, 1 year (12 months) for traction field, crossing construction site and Construction Road area. The natural recovery period is determined according to the actual recovery situation of different provinces. Xinjiang, Gansu and Ningxia sections are calculated as 2-3 years, Shaanxi Henan section as 2 years, Anhui section as 1 year The forecast period of Xinjiang, Gansu and Ningxia is the longest, followed by Henan Province and Anhui Province. However, compared with the newly increased soil and water loss per unit area, Xinjiang and Gansu are the lowest, about $0.6 \mathrm{t} / \mathrm{hm} 2$, while Ningxia, Shaanxi, Henan and Anhui sections increase gradually. Combined with the field survey of power transmission and transformation projects, the characteristics of engineering construction disturbance in different provinces and regions are similar.

Taking the parameters in the universal soil loss equation (USLE) as an example, the slope factor s, slope length factor $\mathrm{L}$ and vegetation factor $\mathrm{C}$ are similar in different provinces and regions, and the soil erodibility factor $\mathrm{K}$ and rainfall erosivity factor $\mathrm{R}$ are different due to different spatial regions. It can be seen that the prevention and control of rainfall erosion and the increase of surface coverage are still the key to control the intensity of soil and water loss during the construction period.

In the construction process, it is still necessary to control the water erosion influencing factors, such as reducing the exposed area, reducing the slope length, increasing the surface coverage, setting up blocking and drainage measures, etc.

\section{Implementation of soil and water conservation measures}

\section{1 implementation of soil and water conservation measures}

The soil and water conservation measures of the line project mainly consider setting slope protection and drainage in tower base area, and land consolidation is considered in other areas. Among them, gravel cover is adopted in Xinjiang section, and cultivated land restoration measures are taken after Gansu Province. The slope protection and drainage ditch adopt the form of masonry slope protection; the temporary measures mainly include temporary retaining, increasing temporary cover, paving and isolation measures of colored strip cloth, temporary sedimentation tank and temporary drainage measures; the plant measures include sowing grass seeds in tower base area, artificial auxiliary vegetation restoration measures such as forest land restoration and grass seed sowing in traction field, crossing construction site and Construction Road area; (it was seen in Table 2).

\section{2 implementation of soil and water conservation measures}

The overhead transmission line project has long distance, scattered construction disturbance, and obvious differences in soil and precipitation conditions among regions. At the same time, restricted by the topography and transport property, The implementation effect of soil and water conservation measures needs to be improved. It is mainly manifested in the following aspects: 
(1) Limited by topography, transport and technical property, the protective measures and effects of the construction site along the slope are not good enough, especially in the areas with poor water - fertilizer in soil and rainfall conditions, and the vegetation restoration effect needs to be improved.

(2) The same project has a large geographical span, different soil and precipitation conditions are obviously different, the soil and water conservation measures are lack of regional pertinence, and the prevention and control effect of soil and water loss is lagging behind or the recovery effect is not better.

(3) technology and natural conditions seriously astrict the maintenance of soil and water conservation measures implemented development. The vegetation restoration measures implemented in various regions have achieved the designed soil and water conservation effect for a long time. During the restoration period of vegetation function, soil erosion exists in different degrees.

Table 2. Allocation of soil and water conservation measures

\begin{tabular}{|c|c|c|c|c|}
\hline \multirow{2}{*}{$\begin{array}{c}\text { Division of } \\
\text { Prevention and } \\
\text { Control }\end{array}$} & \multicolumn{2}{|c|}{ Engineering measures } & \multirow{2}{*}{$\begin{array}{c}\text { Temporary measures (6 } \\
\text { provinces) }\end{array}$} & \multirow{2}{*}{$\begin{array}{l}\text { Plant measures } \\
\text { (6 provinces) }\end{array}$} \\
\hline & Xinjiang Region & $\begin{array}{l}\text { Gansu, Ningxia, Shaanxi, Henan } \\
\text { and Anhui }\end{array}$ & & \\
\hline \multirow{7}{*}{ Tower foundation } & Slope protection & Masonry slope protection & \multirow{7}{*}{$\begin{array}{l}\text { Protection by soil in bags; } \\
\text { Bedded and covered } \\
\text { protection by striped cloth; } \\
\text { Surround protection by color } \\
\text { striped; flag } \\
\text { Sedimentation tank }\end{array}$} & \multirow{7}{*}{ Sowing grass seeds } \\
\hline & Drainage channel & Masonry drainage channel & & \\
\hline & & Topsoil stripping & & \\
\hline & Gravel cover & Topsoil reply & & \\
\hline & & L and consolidation & & \\
\hline & Land consolidation & Land consontation & & \\
\hline & & (1) tain & & \\
\hline Troution find & lidat & Land consolidation; & bedded by striped cloth & Restored to woodland; \\
\hline Iraction field & Land consolidation & Farmland restoration & $\begin{array}{l}\text { striped; flag } \\
\text { s. }\end{array}$ & ass seeds \\
\hline \multirow{2}{*}{$\begin{array}{l}\text { Crossing construction } \\
\text { site }\end{array}$} & \multirow{2}{*}{ Land consolidation } & Land consolidation; & & \multirow{2}{*}{$\begin{array}{l}\text { Restored to woodland } \\
\text { Sowing grass seeds }\end{array}$} \\
\hline & & Farmland restoration & & \\
\hline Construction road & Land consolidation & Land consolidation； & $\begin{array}{l}\text { Temporary drainage ditch; } \\
\text { Plain soil compaction }\end{array}$ & $\begin{array}{l}\text { Restored to woodland } \\
\text { Sowing grass seeds }\end{array}$ \\
\hline
\end{tabular}

\section{3 suggestions on allocation of soil and water conservation measures}

According to the acceptance report of water and soil conservation facilities of this project, except for a small amount of adjustment of engineering measures construction due to actual terrain, other design measures have been basically implemented. However, field investigation shows that there is still room for improvement in vegetation restoration effect. In order to better realize the win-win goal of "safe engineering and environment-friendly", taking the restoration of ecology as the guidance, it is suggested that on the basis of the conventional "engineering + plant" protection measures system, "adjust measures to local conditions" and "fortify according to hazards" should be configured in three-dimensional and multidimensional ways.

(1) Strengthen construction management and incorporate water and soil conservation into the main construction process management of the project.

Adopt high and low leg tower base, aerial photo line selection, and GPS alignment technology to reduce disturbance range and disturbance intensity; Comprehensive utilization of foundation pit and foundation excavation earthwork shall be considered first, and then it shall be stored according to the design, and blocking and covering measures shall be taken to control the disturbance range from the source.
Short construction period for single tower foundation of overhead transmission line.

After the earthwork construction such as excavation, pouring, and backfilling is completed, land improvement and restoration measures should be implemented as soon as possible to ensure the natural restoration cycle of vegetation.

(2) Adopt new technologies of anti-erosion and vegetation promotion and consolidation planting to improve the anti-erosion ability of exposed loose slopes

The anti-erosion and vegetation promotion material (W-OH) developed during the "12th Five-Year Plan" period of the Yellow River Institute of Hydraulic Research is a modified hydrophilic polyurethane composite material ${ }^{[3]}$. After spraying w-oh solution, a 1 mm thick coating layer can be formed on the exposed slope surface and loose waste slag surface, which can improve the adhesion of loose particles, and at the same time, the material has water seepage and moisture retention. The results show that the erosion amount of steep slope can be reduced by more than $90 \%$ after spraying anti erosion and vegetation promotion materials.

On the basis of anti-corrosion and vegetation promotion materials, the perfect consolidation planting ecological slope protection technology in the "13th FiveYear Plan" project is composed of high molar ratio urea formaldehyde slow-release fertilizer, ecological curing agent and functional agent. It can keep moisture, maintain fertilizer and consolidate, and does not affect 
rainfall infiltration, and can improve the vegetation restoration effect in bare, arid and alpine areas. The results show that the application of ecological slope protection technology of consolidation planting can improve the germination and survival rate of grass seeds ${ }^{[3-5]}$.

The use of the above two technologies in the restoration of the fragmented construction sites of overhead transmission lines is expected to reduce soil erosion caused by construction and effectively improve the ecological restoration of construction sites.

\section{Conclusion and discussion}

The overhead transmission line projects are long, soil and precipitation along the line affect ecological restoration conditions, and site conditions in different disturbed areas vary greatly. Conventional water and soil conservation measures have obvious effects on soil erosion control, but the effect of ecological restoration needs to be improved.

The spraying of anti-corrosion and vegetation promotion materials and consolidated planting composite materials can play a role in soil and water conservation. In the artificial promotion of vegetation restoration, the spraying link of the materials can be increased by combining the implementation of engineering measures and plant measures in the construction.

\section{Acknowledgments}

This work was supported by the Research project on key technology of soil and water conservation design and construction about overhead transmission line project in Hilly Area (B3440920K007)

\section{References}

1. Li Chunquan. Analysis and countermeasures of soil and water loss in the power transmission line project which is locate in "red-bed of central part of Yunnan" [J]. Shanxi Architecture, 2015,41 (2): 4445

2. Wu Wenyi, Shi Yuzhu, Pei Hua, et al. Soil and Water Conservation Measures of $500 \mathrm{kV}$ Overhead Power Transmission Lines in Earth-rocky Mountainous Area of Southwestern China [J]. Bulletin of Soil and Water Conservation, 2011,31 (6): 108-112;

3. Xiao Peiqing, Yao Wenyi, Shen Zhenzhou, et al. Resistance to Erosion and Growth Promoting Technique of Pisha Sandstone Region in the Middle Yellow River [J]. Soil and Water Conservation in China, 2016 (9): 73-75

4. Yao Wenyi, Wu Zhiren, Liu Hui, et al. Experimental Research on the Anti- Erosion and Vegetation Promotion for Sandstone Region in the Yellow River Basin [J]. Yellow River, 2015, 37 (1): 6-10
5. Zhang Lei, Feng Weifeng, Qiao Bei, et al. Study on the Influence of W-OH-SF Agent on Plant Germination in Pisha Sandstone Area [J]. Yellow River, 2016,38 (6): 39-41

6. Liu Hui. Ecological protection technology of consolidated vegetation [J]. Yellow River, 2019 (4): 166 